\title{
Specific detection of bioavailable phenanthrene and mercury by bacterium reporters in the red soil
}

\author{
H. Wei $\cdot$ S. Ze-Ling $\cdot$ C. Le-Le $\cdot$ Z. Wen-hui $\cdot$ \\ D. Chuan-Chao
}

Received: 22 May 2012/Revised: 12 February 2013/Accepted: 23 February 2013/Published online: 16 March 2013

(C) Islamic Azad University (IAU) 2013

\begin{abstract}
Genetically engineered Pseudomonas putida reporters (BMB-PL and BMB-ME), which, respectively, carried $p h n S$-luxCDABE and merR-egfp cassette, were used to determine bioavailable phenanthrene and mercury. Over a spiked range of concentrations and aged for 6 days in red soil samples, the reporters were tested to determine the optimal assay conditions and the bioavailable phenanthrene $\left(0-60 \mathrm{mg} \mathrm{kg}^{-1}\right)$ and $\mathrm{Hg}^{2+}\left(0-240 \mu \mathrm{g} \mathrm{kg}^{-1}\right)$ were evaluated by the signal of the relative fluorescent units and relative luminescence units. Single contamination was carried out and good correlations were obtained between signal strength and pollutant concentrations, whereas interference and bioavailability repression were observed in dual-contamination experiments. Other heavy metal ions at nanomolar level did not interfere with BMB-ME measurement while BMB-PL showed some response to other polycyclic aromatic hydrocarbons or their intermediate products during degradation. Comparing high-performance liquid chromatography methods with the bacterial reporters, both BMB-ME and BMB-PL appeared to have a detection limit (mercury $<40 \mu \mathrm{g} \mathrm{kg}^{-1}$; phenanthrene $<24 \mathrm{mg} \mathrm{kg}^{-1}$ ) similar to the instrumental analysis. Although physical parameters may affect the interaction of pollutants with bioreporter cells, advantages include the inherent biological relevance of the response, rapid
\end{abstract}

\footnotetext{
H. Wei · S. Ze-Ling · C. Le-Le · D. Chuan-Chao ( $₫)$ Jiangsu Key Laboratory for Microbes and Functional Genomics, Jiangsu Engineering and Technology Research Center for Industrialization of Microbial Resources, College of Life Science, Nanjing Normal University, Wenyuan Street, Nanjing 210046, Jiangsu, China e-mail: 13776690639@139.com

Z. Wen-hui College of Geography Science, Nanjing Normal University, Nanjing 210046, Jiangsu, China
}

response time, and potential for field deployment. Our results strongly suggest that the BMB-ME and BMB-PL bioreporters constitute an adaptable system for easily detecting the bioavailability of mercury and phenanthrene in the red soils.

Keywords Biosensor - Contamination · Pseudomonas putida $\cdot$ Red soil

\section{Introduction}

Mercury and phenanthrene (PHE) are environmental pollutants of great risk to public health. They have been classified as two of the priority contaminants by the US Environmental Protection Agency (USEPA) due to their potential carcinogenicity, teratogenicity or acute toxicity (Gao and Zhu 2004; Yan et al. 2004; Toyooka and Ibuki 2007). With rapid urbanization and industrialization throughout the world, mercury and PHE are generated by various industrial activities such as mining and smelting of metalliferous ores, electroplating and incomplete combustion of organic matter. As a ubiquitous environmental pollutant (distributed in air, soils and sediments), PHE is often used as a representative indicator of total polycyclic aromatic hydrocarbons (PAHs) contamination (Cebron et al. 2011; Martin et al. 2012). Mercury is also a representative heavy metal (HM) pollutant. Both the presence and risks associated with these compounds in the environment warrant further study.

It is now accepted that bioavailability is a better indicator of risks than total chemical load (Shuttleworth and Cerniglia 1995; Peijnenburg et al. 2004). Measuring bioavailability of mercury and PHE has become essential for calculating their transformation rates, determining toxicity and biodegradability and thereby predicting their 
bioaccumulation in different environments (Barkay et al. 1998). However, the bioavailability of pollutants may vary under the influence of mass transfer parameters, which include physicochemical processes governing dissolution, desorption and diffusion, hydrological processes like mixing and, finally, biological processes, such as uptake and metabolism (MacLeod et al. 2001; Johnsen et al. 2005). At the same time, almost all long-term contaminated sites contain more than one pollutant. This raises questions with regard to the differences in bioavailability between single and multiple chemical pollutants. It is important to determine whether one pollutant alters the transfer parameters of another and thereby affect its bioavailability, and how to assess their bioavailability in a convenient way (Stiner and Halverson 2002; Impellitteri et al. 2003).

In recent years, a number of genetically engineered whole-cell bacterial based PAH (include naphthalene fluorene, PHE, anthracene) and $\mathrm{Hg}^{2+}$-specific reporters have been reported and used to detect target chemicals through induced expression of spectroscopically luminescent, chromo- or fluorogenic proteins (Selifonova et al. 1993; Hansen and Sorensen 2000; Kohler et al. 2000; Petanen et al. 2001; Hakkila et al. 2002; Ivask et al. 2002; Petanen and Romantschuk 2002; Belkin 2003; Van der Meer et al. 2004). Even though some of the research focused on the nonspecific detection of pollutants, those reporters possess the ability for semi-quantitative measurements, as obtained with chemical methods, but with inherent biological relevance, for the reporters in principle respond to exactly the fraction of target compound that passes through its cell during the time of the experiment (Van der Meer et al. 2004). Compared with traditional methods like ecotoxicological or cytogenetic assays such as micronuclei test, chromosome aberration and stamen hair mutation assay, the whole-cell bacterial reporters have several advantages in that they are more convenient, effective and specific. However, there seems to be few reports demonstrating biosensors for PHE assessment, and many previous studies focused mainly on contamination by a single pollutant. The whole-cell bacterial reporter method has not received great attention for the simultaneous detection of two or more kinds of pollutants and their bioavailability in one environmental system, especially in soils.

Different pollutants may have different bioavailability in different environmental systems. This is mainly because the bioavailability of pollutants in the environment is influenced by multiple factors such as low aqueous solubility, redox potential, ionic strength, organic matter and difficulties in controlling the physiological activities of the bacterial reporters. This makes it hard to establish a stable relationship between pollutants and their bioavailability (Semple et al. 2003; Benbelkacem et al. 2004; Nadim 2009). In this study, degraded red soil (ultisols and oxisols in US soil taxonomy) was identified as an environmental system polluted by mercury and PHE. Red soil is widespread in the tropical and subtropical areas in the southern part of China, covering about 1.13 million $\mathrm{km}^{2}$ or $11.8 \%$ of the national land area (Zhong et al. 2007). Owing to the incredible speed of economic and industrial development in the region, red soil has been under tremendous pressure of population growth and environmental pollution. A simple, rapid, and sensitive measurement of pollutants like HMs and PAHs (represented by mercury and PHE) is required. The unique characteristics of red soil such as acerbity, viscidity, leanness, drought and rich aluminiferous ferralsols with low silicon, also provide a unique environment in which to investigate the relationship between red soil and the availability of pollutants.

In this study, a whole-cell bacterium reporter (BMB-PL) was constructed and applied with BMB-ME, created in our previous work, to detect bioavailable PHE and mercury in the red soil of China. The relative luminescent or fluorescent units produced by the reporters were measured and used to establish a stable, specific, and highly sensitive measurement. PHE and $\mathrm{Hg}^{2+}$ are analytes with environmental relevance that promised to improve our understanding of PAH and HM bioavailability. Finally, the bioavailable fraction of both PHE and $\mathrm{Hg}^{2+}$ during the same experimental time was estimated in contaminated red soil by applying the reporters. Results reported here indicate excellent agreement between the biological and the chemical approach for samples having complex matrices that can exhibit strong effects on bioavailability. At the same time, it was also indicated that the bioavailability of single contaminants is different from that of multiple contaminants.

\section{Materials and methods}

Unless otherwise stated, all chemicals used were analytical reagent grade or better and were purchased from SigmaAldrich (Shanghai, China). Restriction endonucleases, DNA polymerase, T4 DNA ligase were supplied from TaKaRa Biotechnology Corporation (Dalian, China). DNA primers and fragments were sequenced or synthesized by Genscript Corporation (Nanjing, China). All media and buffer solutions were prepared using distilled de-ionized water (Milli-Q Plus system, Millipore, MA). All plasmids and bacterial strains were stored in our laboratory unless stated.

Samples of top soils $(5-15 \mathrm{~cm})$ were collected from the Ecological Experimental Station of Red Soil, Chinese Academy of Sciences, located in Yingtan, Jiangxi Province, China $\left(28^{\circ} 15^{\prime} 30^{\prime \prime} \mathrm{N}, 116^{\circ} 55^{\prime} 30^{\prime \prime} \mathrm{E}\right)$. Soils of this region are derived from quaternary red clay, dominated by 
kaolinite and hydrous mica, and also contain a small amount of vermiculite. The samples were first sieved through a $10 \mathrm{~mm}$ and then a $2-\mathrm{mm}$ sieve to remove roots and other vascular material. A detailed chemical analysis was carried out and the results showed that total C, N, P, K and $\mathrm{pH}$ were $1.5,0.10,0.033,0.550 \%$ and 6.6 , respectively. PHE and $\mathrm{Hg}^{2+}$ were not detected by high-performance liquid chromatography (HPLC) in extracts from uncontaminated red soil. All soil samples were sterilized at $121{ }^{\circ} \mathrm{C}, 30 \mathrm{~min}$ before use.

Using a single-step spiking/rehydration procedure (Reid et al. 2000), PHE (methanol solution at $500 \mathrm{mg} \mathrm{L}^{-1}$ ) or mercuric chloride (water solution $543 \mu \mathrm{g} \mathrm{L}^{-1}$ ) was added to soils at a range of concentrations of dry weight soil. Soil samples were mixed thoroughly and left for solvent evaporation for 2 days then adjusted to water content $(w / w)$ at $50 \%$. The soil samples were supplemented with the desired amount of PHE or $\mathrm{Hg}^{2+}$ in two ways: (1) single contamination, PHE or mercuric chloride was added to different soil samples separately; (2) dual contamination, PHE and mercuric chloride were added to the same soil sample. Control soil samples were used throughout to control for the effect of solvent and soil PHE, $\mathrm{Hg}^{2+}$ concentrations were confirmed analytically.

A 2.5-kb fragment containing the complete $p h n R / p h n S$ promoter region was synthesised by Genscript Corporation (Nanjing, China). This fragment was engineered to have BamHI and NcoI restriction sites on both ends and was ligated with a $5.8-\mathrm{kb}$ promoterless bacterial luciferase gene cassette (luxCDABE) which was amplified from $\mathrm{pMH} 31$ using a pair of primers (L-NcoI: $5^{\prime}$-cgaccatggatgactaaaaa- $3^{\prime}$ and L-BamHI: $5^{\prime}$-cggggatcctcaactatcaaac-3'). This combined fragment was cloned into a broad host range vector pCM-62 (Marx and Lidstrom 2001) which was obtained from Dr. Shang Guang-dong (Nanjing Normal University). The resultant plasmid pCM-PL carried the $p h n R$ gene and expressed the presumed regulatory protein which can recognize PHE and form compounds to drive the phnS promoter to express the downstream luxCDABE cassette, encoding the bacterial luciferase protein (Close et al. 2012). Heat shock (Kim et al. 2003) was then used to transform pCM-PL into a wild-type Pseudomonas putida N1 strain which was acquired from China General Microbiological Culture Collection Center (Accession number: 1.1003), and resulted BMB-PL. BMB-ME expresses enhanced green fluorescent protein (EGFP) in response to $\mathrm{Hg}^{2+}$ was used as described in the previous work (Wei et al. 2010). Escherichia coli DH5 $\alpha$ was used for the maintenance of plasmids in all DNA manipulation steps except for the construction of BMB-PL.

Bacterial strains of $P$. putida were cultivated with Luria-Bertani medium (LB, containing $10 \mathrm{~g}^{-1}$ tryptone, $5 \mathrm{~g} \mathrm{l}^{-1}$ yeast extract, $10 \mathrm{~g}^{-1} \mathrm{NaCl}, \mathrm{pH}$ 7.0-7.2) and were grown at $28{ }^{\circ} \mathrm{C}$. Strains carrying reporter plasmids were cultured in LB or on agar plates supplemented with $50 \mu \mathrm{g} \mathrm{mL}^{-1}$ tetracycline. Overnight (ON) cultures were diluted 100-fold into fresh medium supplemented with tetracycline and incubated at $28{ }^{\circ} \mathrm{C}$ in an orbital shaker at $225 \mathrm{rpm}$ until the optical density at $600 \mathrm{~nm}\left(\mathrm{OD}_{600}\right)$ reached 0.6 .

Filter paper was punched into 5-mm diameter round flakes, soaked in potassium hydroxide containing $5 \%$ potassium hydroxide $(\mathrm{w} / \mathrm{v})$ for $10 \mathrm{~min}$, and rinsed with de-ionized distilled water. After drying at $50{ }^{\circ} \mathrm{C}$ for $1 \mathrm{~h}$, flakes were then dipped into the buffer solution $[33 \mathrm{mM}$ $\mathrm{NaH}_{2} \mathrm{PO}_{4}, \quad 33 \mathrm{mM} \quad \mathrm{K}_{2} \mathrm{HPO}_{4}, \quad 0.09 \mathrm{mM} \quad\left(\mathrm{NH}_{4}\right)_{2} \mathrm{SO}_{4}$, $50 \mu \mathrm{g} \mathrm{mL}^{-1}$ tetracycline and $5 \mathrm{mM}$ glucose at $\mathrm{pH}$ 6.8] for $10 \mathrm{~min}$. After drying at $50{ }^{\circ} \mathrm{C}$ again, $5 \mu \mathrm{L}$ of refreshed BMB-PL ON cultures $\left(\mathrm{OD}_{600}=0.6\right)$ was added to the surface of the flakes. A second dry flake was then gently placed on top of the first flake to immobilize the BMB-PL reporter system and could then be used directly for the detection of PHE. The prepared double flakes were kept in a petri dish and could be incubated for several days in a cultural incubator with constant temperature at $28{ }^{\circ} \mathrm{C}$ and $50 \%$ humidity. The immobilization procedure for BMBME was the same, except that tetracycline was not included in the buffer solutions.

The induction assays were carried out in both single and dual-contaminated soil samples prepared as described above. The induction procedures were as follows: $500-\mathrm{mL}$ beakers were prepared and loaded with $200 \mathrm{~g}$ red soil samples which were spiked with different concentrations of $\mathrm{Hg}^{2+}$ or PHE. Thirty doubled flakes containing immobilized BMB-ME or BMB-PL were distributed evenly onto the leveled soil surface. Another $200 \mathrm{~g}$ spiked red soil was added to bury the doubled flakes $5 \mathrm{~cm}$ under the surface horizon. The beakers were then transferred into an incubator with constant temperature at $28{ }^{\circ} \mathrm{C}$ and $50 \%$ humidity and incubated 1-6 days in the dark. At intervals for the duration of the experiment, 5 doubled flakes buried in the contaminated soil samples were taken out and collected in 2-mL Teflon centrifuge tubes. De-ionized distilled water was added $(1.5 \mathrm{~mL})$ to all tubes which were then placed on an orbital mixer (Eppendorf, Thermomixer comfort) and shaken at $400 \mathrm{rpm}, 30{ }^{\circ} \mathrm{C}$ for $10 \mathrm{~min}$. After centrifugation at $500 \times g$ for $1 \mathrm{~min}, 0.5 \mathrm{~mL}$ supernatant was retained and impurities like paper flakes and soil particles were eliminated. Viable cell numbers (colony forming unit, $\mathrm{CFU}$ ) and the signals produced by the reporters were measured by dilution-plate and luminescence spectrometer Shimadzu RF-540. For fluorescence measurements, samples were excited at $380 \mathrm{~nm}$ and measured at $509 \mathrm{~nm}$. The specific fluorescence intensity (SFI) and specific bioluminescence intensity (SLI) are defined as RFU and RLU, respectively, divided by the viable cell 
numbers (CFU) measured at each concentration and time point.

A series of orthogonal experiment combinations were also conducted to optimize the conditions of signal inductions. Nine basic orthogonal arrays were tabulated. The notation of each orthogonal array is expressed by its number of rows and letters of columns, as well as the number of levels in each column. The $\mathrm{L}_{9}\left(3^{4}\right)$ orthogonal arrays, for example, have 9 rows and 4 three-level columns. Based on the meteorological and environmental data of the site where the red soil samples were collected, the concentration of total carbon in the soil (TC: 15, 20, $25 \mathrm{~g} \mathrm{~kg}^{-1}$ ), induction time (IT: 1, 3, 6 days), soil water content (WC: 20, 40, $60 \%$ ) and temperature (20, 25, $30{ }^{\circ} \mathrm{C}$ ) were set as four influencing factors on induction response of BMB-ME at $0.1 \mathrm{mg} \mathrm{kg}^{-1} \mathrm{Hg}^{2+}$ and BMB-PL at $50 \mathrm{mg} \mathrm{kg}^{-1} \mathrm{PHE}$. Each factor was set at three levels as 0,1 and 2. RFU or RLU were measured using the same method as the induction assay.

PHE in soil samples was extracted and cleaned up as previously described (Wang et al. 2010). Water-soluble (WS) $\mathrm{Hg}^{2+}$ was extracted from soil samples contaminated by $\mathrm{HgCl}_{2}$ and the analysis of $\mathrm{Hg}^{2+}$ in the extractions was carried out by HPLC. Analysis of PHE in the extractions was performed by a HPLC (WATERS 515; USA) fitted with a UV detector and a $4.6 \mathrm{~mm} \times 250 \mathrm{~mm}$ reversephase $\mathrm{C}_{18}$ column using methanol as the mobile phase at a flow rate of $0.65 \mathrm{~mL} / \mathrm{min}\left(40{ }^{\circ} \mathrm{C}\right)$. Aliquots $(20 \mu \mathrm{L})$ of each sample were injected into the HPLC system by an auto-sampler. PHE identification was performed by comparison of its retention time with standards and quantification was calculated from the peak area.

All the data were statistically processed using Microsoft Office Excel 2007 and SPSS 13.0. Treatments were replicated three times in the experiments to ensure statistical significance of results (significance was accepted at $P<0.05)$. The images of luminescence and fluorescence expression were acquired using an Olympus BX-41 fluorescence microscope.

Statistical analyses using the general linear model (GLM procedure) in the SAS package were made to identify those variations and/or four-factor interactions that had a significant impact on the signal expression of reporters.

\section{Results and discussion}

The pCM-PL plasmid that carried a transcriptional fusion between the phnS putative promoter/operator region and a bacterial luciferase gene cassette (luxCDABE) was successfully constructed (Fig. 1). Bioreporter strain BMB-PL was constructed by transformation of the pCM-PL plasmid into $P$. putida strain N1. Growth characteristics for BMB-
PL were the same as for BMB-ME as previously reported (Wei et al. 2010). The strains were shown to express significant fluorescence or bioluminescence in the presence of inducing compounds (Fig. 2).

The influence of four factors (TC, IT, WC and temperature) on fluorescence and bioluminescence expression by the two strains were assessed. Statistical differences in these results were listed in Table 1 and evaluated by analysis of variance. According to the $F$ ratio, the order of influence of the four factors $\mathrm{D}, \mathrm{B}, \mathrm{C}, \mathrm{A}$, indicating that temperature may be one of the key factors affecting EGFP expression. Bioluminescence produced by the lux gene was mostly affected by the total $\mathrm{C}$ in soil, and temperature also a significant influence on the luminescence signal.

Both the highest RFU and RLU were found in experimental trial No. 3 (Table 1). Based on the average RFU and RLU of three experimental trials at each level, the highest levels of signals for different factors are A0, B2, C2, D2, which indicate that EGFP and LUX were best expressed when the TC was $15 \mathrm{~g} \mathrm{~kg}^{-1}$, the IT was 6 days, the WC was $60 \%$ and the temperature was $30^{\circ} \mathrm{C}$.

Under the optimal assay conditions determined above, the RFU and RLU increased as the soil concentration of $\mathrm{Hg}^{2}$ and PHE increased from 0 to $240 \mu \mathrm{g} \mathrm{kg}^{-1}$ and 0 to $60 \mathrm{mg} \mathrm{kg}^{-1}$, respectively (Fig. 3). Limits of detection for $\mathrm{Hg}^{2+}$ (BMB-ME) and PHE (BMB-PL) were below $40 \mu \mathrm{g} \mathrm{kg}^{-1}$ and $10 \mathrm{mg} \mathrm{kg}^{-1}$, respectively. The good correlations obtained $\left(R^{2}=0.987\right.$ and 0.994$)$ demonstrates that both BMB-ME and BMB-PL can be used to quantify $\mathrm{Hg}^{2+}$ and $\mathrm{PHE}$ within a certain concentration range. The luminescent signal decreased rapidly to 0 at $300 \mu \mathrm{g} \mathrm{kg}^{-1}$ (data not shown), probably due to the strong toxic effect of $\mathrm{Hg}^{2+}$ ions.

BMB-ME is highly specific to the target $\mathrm{Hg}^{2+}$ ions, and most of the other heavy metal ions tested did not interfere with the measurement of $\mathrm{Hg}^{2+}$ in the concentration range from $200 \mathrm{nM}$ to $1.2 \mathrm{mM}$ (Wei et al. 2010), whereas BMBPL was weakly induced by naphthalene, salicylate and

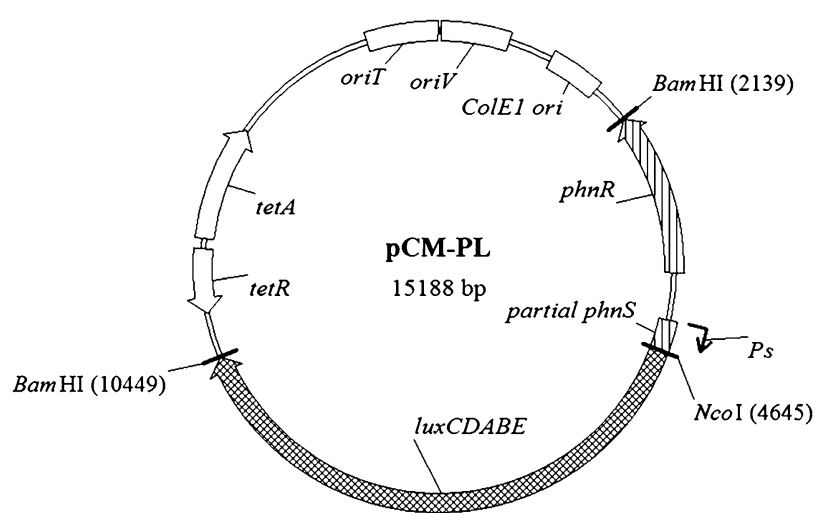

Fig. 1 Structure and restriction map of pCM-PL 

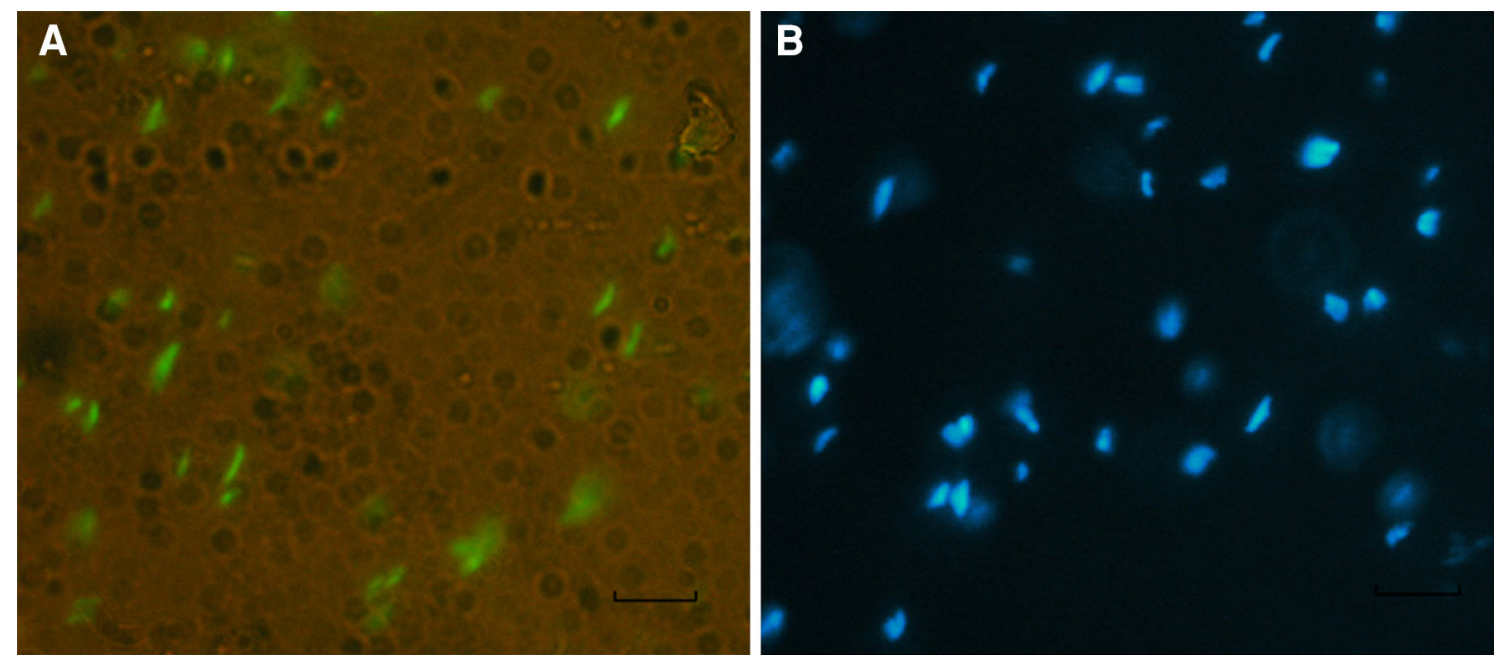

Fig. 2 The induction of BMB-ME and BMB-PL by $\mathrm{Hg}^{2+}$ and PHE. a BMB-ME fluorescence in visible light. b BMB-PL luminescence in the dark. Bar $10 \mu \mathrm{m}$

Table 1 Layout of the $\mathrm{L}_{9}\left(3^{4}\right)$ matrix and results for the effect of combined factors on RFU and RLU

\begin{tabular}{|c|c|c|c|c|c|c|c|c|c|c|c|}
\hline \multicolumn{6}{|c|}{ BMB-ME } & \multicolumn{6}{|c|}{ BMB-BL } \\
\hline No. & $\begin{array}{l}\text { A } \\
\text { TC }\end{array}$ & $\begin{array}{l}\text { B } \\
\text { IT }\end{array}$ & $\begin{array}{l}\mathrm{C} \\
\mathrm{WC}\end{array}$ & $\begin{array}{l}\mathrm{D} \\
\mathrm{T}\end{array}$ & Average RFU & No. & $\begin{array}{l}\mathrm{A} \\
\mathrm{TC}\end{array}$ & $\begin{array}{l}\text { B } \\
\text { IT }\end{array}$ & $\begin{array}{l}\mathrm{C} \\
\mathrm{WC}\end{array}$ & $\begin{array}{l}\mathrm{D} \\
\mathrm{T}\end{array}$ & Average RLU \\
\hline 1 & 0 & 0 & 0 & 0 & 52 & 1 & 0 & 0 & 0 & 0 & 50.6 \\
\hline 2 & 0 & 1 & 1 & 1 & 113 & 2 & 0 & 1 & 1 & 1 & 113.0 \\
\hline 3 & 0 & 2 & 2 & 2 & 245 & 3 & 0 & 2 & 2 & 2 & 165.0 \\
\hline 4 & 1 & 0 & 1 & 2 & 187 & 4 & 1 & 0 & 1 & 2 & 105.0 \\
\hline 5 & 1 & 1 & 2 & 0 & 66 & 5 & 1 & 1 & 2 & 0 & 98.0 \\
\hline 6 & 1 & 2 & 0 & 1 & 134 & 6 & 1 & 2 & 0 & 1 & 134.0 \\
\hline 7 & 2 & 0 & 2 & 1 & 145 & 7 & 2 & 0 & 2 & 1 & 102.5 \\
\hline 8 & 2 & 1 & 0 & 2 & 205 & 8 & 2 & 1 & 0 & 2 & 58.0 \\
\hline 9 & 2 & 2 & 1 & 0 & 86 & 9 & 2 & 2 & 1 & 0 & 83.0 \\
\hline$K_{0}$ & 410 & 384 & 391 & 204 & & $K_{0}$ & 329 & 258 & 243 & 232 & \\
\hline$K_{1}$ & 387 & 384 & 386 & 392 & & $K_{1}$ & 337 & 269 & 301 & 350 & \\
\hline$K_{2}$ & 436 & 465 & 456 & 637 & & $K_{2}$ & 244 & 382 & 366 & 328 & \\
\hline$F$ ratio & 0.01 & 0.05 & 0.03 & 1.00 & & $F$ ratio & 0.68 & 1.19 & 0.96 & 1.00 & \\
\hline
\end{tabular}

$K_{0}, K_{1}$ and $K_{2}=$ means of the average RFU or RLU at levels 0,1 and 2, respectively

$T C$ total carbon, $I T$ induction time, $W C$ water content, $T$ temperature

pyruvate (data not shown). It was assumed that no induction would occur in the presence of other PAHs whose solubility in water is even lower than PHE $\left(0.076 \mathrm{mg} \mathrm{L}^{-1}\right)$ (Tecon et al. 2006).

According to the results of the optimal assay conditions and the environmental site conditions where red soil samples were collected, the dual-contamination assays of PHE and $\mathrm{Hg}^{2+}$ were carried out under the following conditions: TC was $15 \mathrm{~g} \mathrm{~kg}^{-1}$, IT was 6 days, WC was $60 \%$ and the temperature was $30{ }^{\circ} \mathrm{C}$. Spiked with $0-60 \mathrm{mg} \mathrm{kg}^{-1} \mathrm{PHE}$ and $0-240 \mu \mathrm{g} \mathrm{kg}^{-1} \mathrm{Hg}^{2+}$ at the same time, the red soil samples were tested by BMB-PL and BMB-ME simultaneously. Pollutant concentrations and their induction profiles are presented in Fig. 4. The dual-induction curves were different from single induction curves shown in Fig. 1 and the trend lines showed steeper slopes. The induction curve for BMB-ME only changed a little, while significant changes were observed for the BMB-PL induction curve.

Red soil samples spiked with $40-240 \mu \mathrm{g} \mathrm{kg}^{-1} \mathrm{HgCl}_{2}$ were incubated at $30{ }^{\circ} \mathrm{C}$ and the concentrations of $\mathrm{Hg}^{2+}$ 


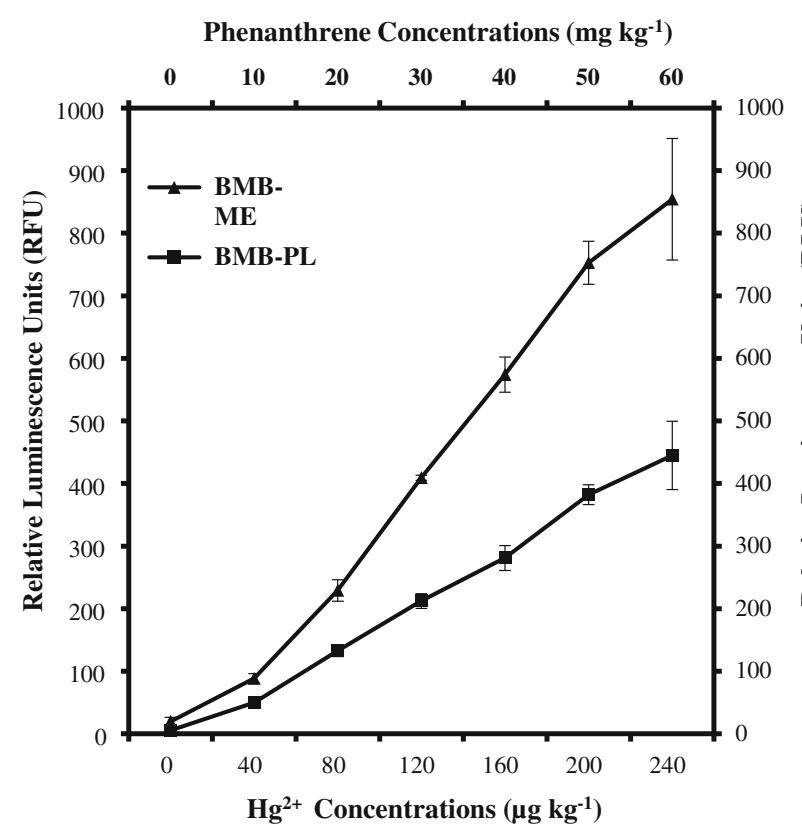

Fig. 3 Induction of BMB-ME and BMB-PL in the presence of single contaminants $\mathrm{Hg}^{2+}$ and $\mathrm{PHE}$, respectively. Values represent mean \pm standard error $(n=3)$ for fluorescence and bioluminescence

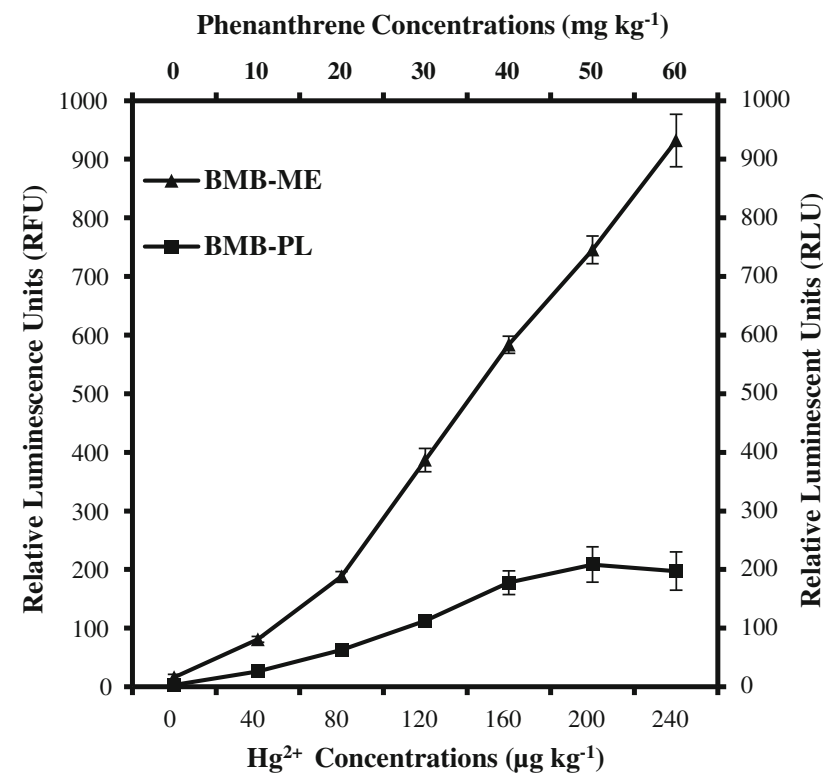

Fig. 4 Induction of BMB-ME and BMB-PL in the presence of both $\mathrm{Hg}^{2+}$ and PHE. Values represent mean \pm standard error $(n=3)$ for fluorescence and bioluminescence

were measured both by HPLC and the BMB-ME method (Fig. 5a). According to the results, about $10-20 \%$ of the $\mathrm{Hg}^{2+}$ was adsorbed in the soil and another $50 \%$ was still in a bioavailable form after 6 days incubation. The total amounts of recovered $\mathrm{Hg}^{2+}$ using both methods were similar. This result was not in agreement with previous studies probably due to the different induction time. By
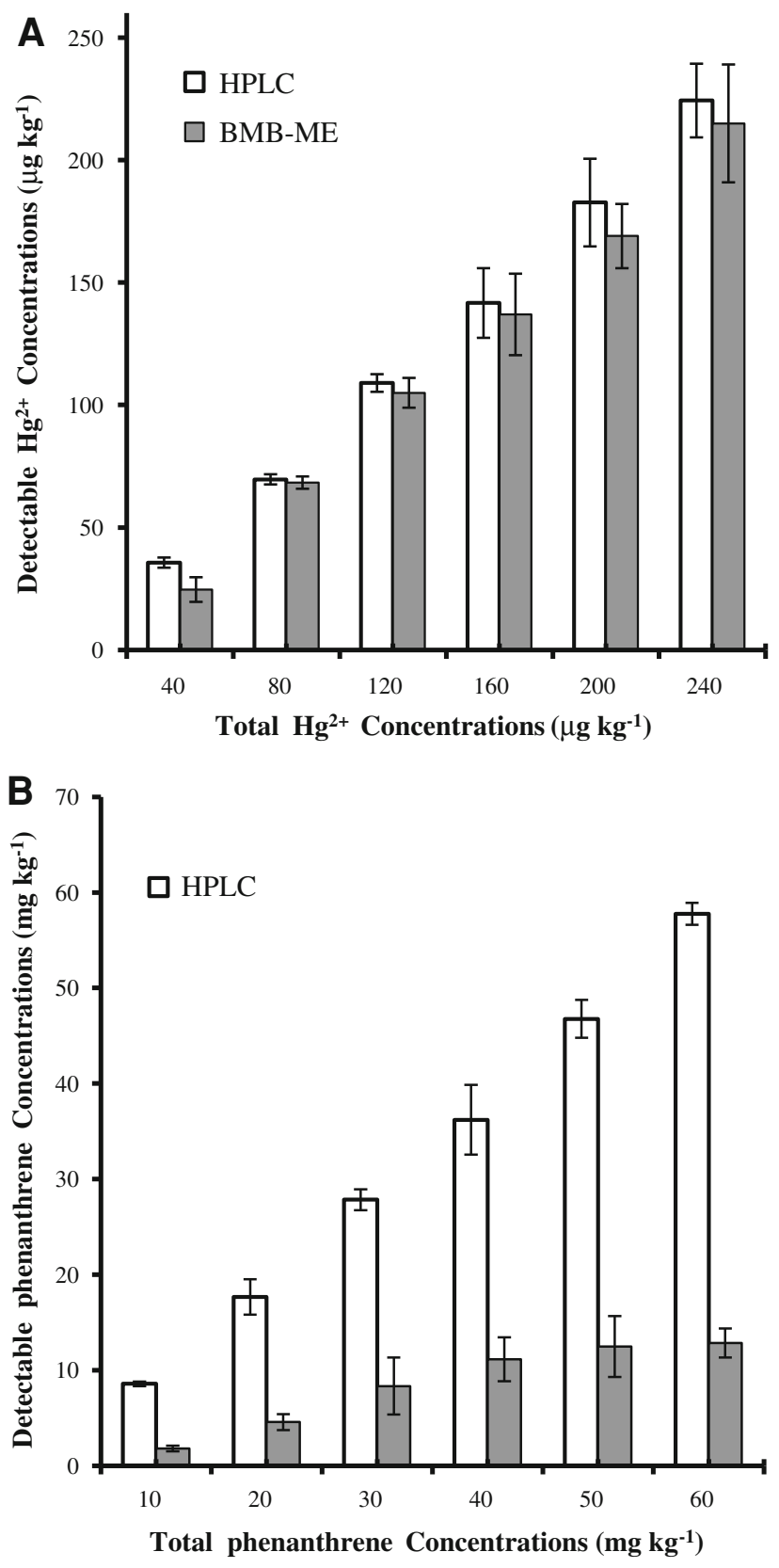

Fig. 5 Comparison between bioreporter and instrumental analysis. a Evaluation of $\mathrm{Hg}^{2+}$ concentrations by HPLC and BMB-ME method. b Evaluation of PHE concentrations by HPLC and BMBPL method. Values represent mean \pm standard error $(n=3)$ for fluorescence and bioluminescence

comparing the relative percentage with the amount of recovered $\mathrm{Hg}^{2+}$, the reporter strain BMB-ME assay and the HPLC methods performed equally well.

HPLC and BMB-PL were also used to detect PHE spiked in the red soil samples during a 1-week incubation period (Fig. 5b). The initial concentration ranged from 10 to $60 \mathrm{mg} \mathrm{kg}^{-1}$, and it is clear that $80 \%$ of the PHE was detected by HPLC. Although the dose-response of BMBPL was still quite good, the bioavailable fraction which 
was determined by BMB-PL was much less than the total amount of PHE, and this was mainly attributed to the sample extraction procedure used for the HPLC method. Meanwhile, this result suggests that, contrary to the soluble mercury contaminants, PHE is stable in the red soil and becomes relatively unavailable to the microbial biosensor within a certain period of time.

Over the last decade, a great deal of interest has focused on the description and measurement of the bioavailability of contaminants in soils and sediments. However, because of the complexity in soil environmental systems and different forms or types of pollutants, it is difficult to determine the interrelationship among organisms, soils and bioavailability of pollutants as a whole. A number of bacterial whole-cell reporters and soil extraction procedures have been constructed and tested. These methods provide an understanding of the relationships between organisms especially microorganisms and chemical compounds. (Applegate et al. 1998; Willardson et al. 1998; Hakkila et al. 2002; Stiner and Halverson 2002; Casavant et al. 2003; Ivask et al. 2004; Paitan et al. 2004), yet the question of suitable reporter systems for different contaminants has seldom been critically examined and compared, as investigated in this study.

This study described the construction, characterization, and comparison of fluorescence and bioluminescence bacterial reporters for the measurement of bioavailable mercury and PHE in the red soil of China. The recombinant bacterial reporters, designated BMB-ME and BMB-PL, were based on expression of the $g f p$ and $l u x C D A B E$ genes, respectively, under the control of the MerR- $\mathrm{P}_{\text {merT }}$ and PhnR-P $\mathrm{P}_{\text {phns }}$ promoter. Cells harboring these constructs are capable of producing detectable signals upon exposure to $\mathrm{Hg}^{2+}$ and PHE with high sensitivity.

Firstly, on the design of reporter systems, the lux gene expression was used to evaluate the bioavailability of PHE. This is mainly because bacterial luminescence has two major advantages for detecting PAHs and other sparingly soluble compounds: a faster response time and higher shortterm sensitivities (Leonardi et al. 2008). Both advantages allow a relatively small number of reporter molecules to produce a sufficient and strong signal. In this study, a GFPmarked reporter was also constructed for the PHE testing (data not shown), yet its insensitivity against background values and poor response at low PHE doses made it unsuitable for use. The EGFP signal, on the other hand, is stable for it is independent of enzymatic processes. Once induced by an effector, the green fluorescence keeps accumulating and may be detected for a long period of time even after cell death. This is particularly useful for the detection of highly toxic environmental samples, such as $\mathrm{Hg}^{2+}$.

In addition to the genetic constructs, several factors might have also affected the sensitivities and induction coefficients of these biosensors. These include the host strains, induction times, medium compositions, growth phase of the harvested bacteria, and amounts of bacteria per measurement (Tauriainen et al. 1997; Hansen and Sorensen 2000). In this study, both biosensor systems were produced using the same bacterial strain of $P$. putida N1, and cultivation and measurements were performed identically for both the luminescence and fluorescence bacterial biosensors in the dual-contamination assays. This makes it easy to evaluate the performance of each biosensor under the same conditions. Based on the optimization results, temperature seemed to be the key factor that may affect the EGFP signal. This is due to the conditions for growth of the host strain or the slow folding process of GFP proteins, and it has been demonstrated that GFP requires days at room temperature to reach maximal fluorescence (Baird et al. 2000). The total carbon level in the soil samples governed the expression of LUX signal, meanwhile the reporter system did not function when the host strain was replaced by $E$. coli (data not shown). Since the $P$. putida strain has the ability to degrade a range of aromatic compounds, these phenomena seem to be attributed to the bio-degradation process of PHE and this may help to understand why the BMB-PL was weakly induced by other aromatic compounds or their intermediate products, such as naphthalene, salicylate and pyruvate.

Due to the fact that microorganisms can generally assimilate a hydrophobic organic contaminant which is soluble in the aqueous phase, bioavailability assessment of sparingly soluble compounds, such as PAHs, become problems. A number of studies have investigated the use of various extractions as determinants for bioavailability (Echols et al. 2008; Deepthike et al. 2009). However, these methods seem to be imperfect for the reason that chemical solvent extractions, such as acetone and methanol, may not only interfere with the physiology of bacterial reporters, but also do not reflect the true bioavailability in the environment. Some extraction procedures are also very complex and difficult to perform. Here, soluble $\mathrm{Hg}^{2+}$ and sparingly soluble PHE were designated as two typical and representative pollutants. Their in situ bioavailabilities in the red soil of China were evaluated. Without using organic solvent extraction, the different levels of bioavailability indicative of both pollutants were acquired (Figs. 3, 4). It can be seen from the figures, the bioavailability of $\mathrm{Hg}^{2+}$ at microgram level is much higher than PHE at milligram level in the red soil of China. It is unknown whether the bioavailability characteristics obtained in this soil are similar to other soil environments, and this also needs to be further investigated.

Pollution of the environment is often caused by more than one kind of contaminant. The interrelationships of different pollutants and their bioavailability have been 
investigated in a number of studies (Vrana et al. 2001; Lewis et al. 2004; Rastall et al. 2004; Tusseau-Vuillemin et al. 2007). However, these studies focused mainly on contaminant within the same category, such as HMs or PAHs, and whole-cell bacterial reporters to determine the bioavailability of pollutants have seldom been discussed. In this study, a dual contamination by both heavy metal and polycyclic aromatic hydrocarbon was simultaneously carried out, and the bioavailability of both $\mathrm{Hg}^{2+}$ and PHE by each bioreport strain was determined (Figs. 3, 4). Comparing the results of single and dual contaminations, the bioavailability of $\mathrm{Hg}^{2+}$ was barely changed by the presence of PHE, whereas the bioavailability of PHE was significantly repressed when $\mathrm{Hg}^{2+}$ was also present. The total average bioavailability dropped approximately 11-30.6\% in dual compared to single contaminations. This result may due to the acute toxicity of $\mathrm{Hg}^{2+}$, and may also indicate that the total bioavailability of multiple contaminants was dominated by the pollutant which is more soluble and more available to the bacterial cells (Kong et al. 2011).

Many other instruments or techniques can be employed to detect $\mathrm{Hg}^{2+}$ or pollutants in the environment, or to quantify their residuals (Yang et al. 2006). Although other analyses perform well in terms of their accuracy and validity of measurements, they are always focused on the detection of a total amount of contaminants, rather than a direct determination of bioavailability. The whole-cell bacterial reporters in this study, on the other hand, provide a direct relationship between microorganism and $\mathrm{Hg}^{2+}$ or PHE. Bioavailability of $\mathrm{Hg}^{2+}$ was found to be similar using BMB-ME to the values detected using HPLC within a certain concentration range of $\mathrm{Hg}^{2+}$. BMB-PL, however, was not suitable for detecting the total amount of PHE, yet its merits of low-price, convenience and in situ application in the assessment of bioavailability warrant further investigation. The combined use of both instrumental and bioreporter analysis was also recommended.

\section{Conclusion}

In summary, the whole-cell bacterial reporter strains used in this study were able to determine the bioavailable portion of $\mathrm{Hg}^{2+}$ and PHE in the red soil of China, providing critical data that can be useful in risk assessment. They also represent a simple, fast, inexpensive, and less-laborious alternative to conventional HPLC measurement. The greatest advantage of this bacterial reporter method may be the ease with which it can be applied for field testing and used for screening both the presence and bioavailable fractions of more than one contaminant in the environment.
This is particularly useful when a large number of environmental samples need to be analyzed. On the other hand, many abiotic factors may affect the bioavailability of pollutants and the reporter bacterium in soils, such as clay content, $\mathrm{pH}$, dissolved organic carbon and root exudates (Barkay et al. 1997). The internal concentration of bioavailable contaminants for different reporters may give variable results depending on the ability of the host organism to assimilate and degrade pollutants. Therefore, further studies to examine a variety of environments for host bacteria in order to design more reliable reporters and to investigate other potential host strains for situ application deserve close attention.

Acknowledgments The project was financially supported by the Natural Science Foundation of the Jiangsu Higher Education Institutions of China (Grant No. 10KJD610001) and the Priority Academic Program Development (PAPD) of Jiangsu Higher Education Institutions. The authors thank the anonymous reviewers for their valuable comments and suggestions that greatly improved this manuscript.

\section{References}

Applegate BM, Kehrmeyer SR, Sayler GS (1998) A chromosomally based tod-luxCDABE whole-cell reporter for benzene, toluene, ethybenzene, and xylene (BTEX) sensing. Appl Environ Microbiol 64(7):2730-2735

Baird GS, Zacharias DA, Tsien RY (2000) Biochemistry, mutagenesis, and oligomerization of DsRed, a red fluorescent protein from coral. Proc Natl Acad Sci USA 97(22):11984-11989

Barkay T, Gillman M, Turner RR (1997) Effects of dissolved organic carbon and salinity on bioavailability of mercury. Appl Environ Microbiol 63(11):4267-4271

Barkay T, Turner RR, Rasmussen LD, Kelly CA, Rudd JW (1998) Luminescence facilitated detection of bioavailable mercury in natural waters. Methods Mol Biol 102:231-246

Belkin S (2003) Microbial whole-cell sensing systems of environmental pollutants. Curr Opin Microbiol 6(3):206-212

Benbelkacem H, Mathe S, Debellefontaine H (2004) Taking mass transfer limitation into account during ozonation of pollutants reacting fairly quickly. Water Sci Technol 49(4):25-30

Casavant NC, Thompson D, Beattie GA, Phillips GJ, Halverson LJ (2003) Use of a site-specific recombination-based biosensor for detecting bioavailable toluene and related compounds on roots. Environ Microbiol 5(4):238-249

Cebron A, Louvel B, Faure P, France-Lanord C, Chen Y, Murrell JC, Leyval C (2011) Root exudates modify bacterial diversity of phenanthrene degraders in PAH-polluted soil but not phenanthrene degradation rates. Environ Microbiol 13(3):722-736

Close D, Xu T, Smartt A, Rogers A, Crossley R, Price S, Ripp S, Sayler G (2012) The evolution of the bacterial luciferase gene cassette (lux) as a real-time bioreporter. Sensors (Basel) 12(1):732-752

Deepthike HU, Tecon R, Van Kooten G, Van der Meer JR, Harms H, Wells M, Short J (2009) Unlike PAHs from Exxon Valdez crude oil, PAHs from Gulf of Alaska coals are not readily bioavailable. Environ Sci Technol 43(15):5864-5870

Echols KR, Brumbaugh WG, Orazio CE, May TW, Poulton BC, Peterman PH (2008) Distribution of pesticides, PAHs, PCBs, and 
bioavailable metals in depositional sediments of the lower Missouri River, USA. Arch Environ Contam Toxicol 55(2):161-172

Gao Y, Zhu L (2004) Plant uptake, accumulation and translocation of phenanthrene and pyrene in soils. Chemosphere 55(9):11691178

Hakkila K, Maksimow M, Karp M, Virta M (2002) Reporter genes lucFF, luxCDABE, gfp, and dsred have different characteristics in whole-cell bacterial sensors. Anal Biochem 301(2):235-242

Hansen LH, Sorensen SJ (2000) Versatile biosensor vectors for detection and quantification of mercury. FEMS Microbiol Lett 193(1): 123-127

Impellitteri CA, Saxe JK, Cochran M, Janssen GM, Allen HE (2003) Predicting the bioavailability of copper and zinc in soils: modeling the partitioning of potentially bioavailable copper and zinc from soil solid to soil solution. Environ Toxicol Chem 22(6):1380-1386

Ivask A, Virta M, Kahru A (2002) Construction and use of specific luminescent recombinant bacterial sensors for the assessment of bioavailable fraction of cadmium, zinc, mercury and chromium in the soil. Soil Biol Biochem 34(10):1439-1447

Ivask A, Francois M, Kahru A, Dubourguier HC, Virta M, Douay F (2004) Recombinant luminescent bacterial sensors for the measurement of bioavailability of cadmium and lead in soils polluted by metal smelters. Chemosphere 55(2):147-156

Johnsen AR, Wick LY, Harms H (2005) Principles of microbial PAHdegradation in soil. Environ Pollut 133(1):71-84

Kim Y, Webster DA, Stark BC (2003) Evidence for stable transformation of Pseudomonas aeruginosa with a pUC-based plasmid. Biotechnol Lett 25(12):959-962

Kohler S, Belkin S, Schmid RD (2000) Reporter gene bioassays in environmental analysis. Fresenius J Anal Chem 366(6-7):769-779

Kong H, He J, Gao Y, Wu H, Zhu X (2011) Cosorption of phenanthrene and mercury(II) from aqueous solution by soybean stalk-based biochar. J Agric Food Chem 59(22):12116-12123

Leonardi V, Giubilei MA, Federici E, Spaccapelo R, Sasek V, Novotny C, Petruccioli M, D'Annibale A (2008) Mobilizing agents enhance fungal degradation of polycyclic aromatic hydrocarbons and affect diversity of indigenous bacteria in soil. Biotechnol Bioeng 101(2):273-285

Lewis MA, Quarles RL, Dantin DD, Moore JC (2004) Evaluation of a Florida coastal golf complex as a local and watershed source of bioavailable contaminants. Mar Pollut Bull 48(3-4):254-262

MacLeod CJ, Morriss AW, Semple KT (2001) The role of microorganisms in ecological risk assessment of hydrophobic organic contaminants in soils. Adv Appl Microbiol 48:171-212

Martin F, Torelli S, Le Paslier D, Barbance A, Martin-Laurent F, Bru D, Geremia R, Blake G, Jouanneau Y (2012) Betaproteobacteria dominance and diversity shifts in the bacterial community of a PAH-contaminated soil exposed to phenanthrene. Environ Pollut 162:345-353

Marx CJ, Lidstrom ME (2001) Development of improved versatile broad-host-range vectors for use in methylotrophs and other Gram-negative bacteria. Microbiology 147(Pt 8):2065-2075

Nadim A (2009) Modeling of mass transfer limitation in biomolecular assays. Ann NY Acad Sci 1161:34-43

Paitan Y, Biran I, Shechter N, Biran D, Rishpon J, Ron EZ (2004) Monitoring aromatic hydrocarbons by whole cell electrochemical biosensors. Anal Biochem 335(2):175-183

Peijnenburg W, Sneller E, Sijm D, Lijzen J, Traas T, Verbruggen E (2004) Implementation of bioavailability in standard setting and risk assessment. Environ Sci 11(3):141-149
Petanen U, Romantschuk M (2002) Use of bioluminescent bacterial sensors as an alternative method for measuring heavy metals in soil extracts. Anal Chim Acta 456(1):55-61

Petanen T, Virta M, Karp M, Romantschuk M (2001) Construction and use of broad host range mercury and arsenite sensor plasmids in the soil bacterium Pseudomonas fluorescens OS8. Microb Ecol 41(4):360-368

Rastall AC, Neziri A, Vukovic Z, Jung C, Mijovic S, Hollert H, Nikcevic S, Erdinger L (2004) The identification of readily bioavailable pollutants in Lake Shkodra/Skadar using semipermeable membrane devices (SPMDs), bioassays and chemical analysis. Environ Sci Pollut Res Int 11(4):240-253

Reid BJ, Stokes JD, Jones KC, Semple KT (2000) Nonexhaustive cyclodextrin-based extraction technique for the evaluation of PAH bioavailability. Environ Sci Technol 34(15):3174-3179

Selifonova O, Burlage R, Barkay T (1993) Bioluminescent sensors for detection of bioavailable $\mathrm{Hg}(\mathrm{II})$ in the environment. Appl Environ Microbiol 59(9):3083-3090

Semple DM, Ramsden F, McIntosh AM (2003) Reduced binocular depth inversion in regular cannabis users. Pharmacol Biochem Behav 75(4):789-793

Shuttleworth KL, Cerniglia CE (1995) Environmental aspects of PAH biodegradation. Appl Biochem Biotechnol 54(1-3):291-302

Stiner L, Halverson LJ (2002) Development and characterization of a green fluorescent protein-based bacterial biosensor for bioavailable toluene and related compounds. Appl Environ Microbiol 68(4):1962-1971

Tauriainen S, Karp M, Chang W, Virta M (1997) Recombinant luminescent bacteria for measuring bioavailable arsenite and antimonite. Appl Environ Microbiol 63(11):4456-4461

Tecon R, Wells M, van der Meer JR (2006) A new green fluorescent protein-based bacterial biosensor for analysing phenanthrene fluxes. Environ Microbiol 8(4):697-708

Toyooka T, Ibuki Y (2007) DNA damage induced by coexposure to PAHs and light. Environ Toxicol Pharmacol 23(2):256-263

Tusseau-Vuillemin MH, Gourlay C, Lorgeoux C, Mouchel JM, Buzier R, Gilbin R, Seidel JL, Elbaz-Poulichet F (2007) Dissolved and bioavailable contaminants in the Seine river basin. Sci Total Environ 375(1-3):244-256

Van der Meer JR, Tropel D, Jaspers M (2004) Illuminating the detection chain of bacterial bioreporters. Environ Microbiol 6(10):1005-1020

Vrana B, Paschke A, Popp P, Schuurmann G (2001) Use of semipermeable membrane devices (SPMDs). Determination of bioavailable, organic, waterborne contaminants in the industrial region of Bitterfeld, Saxony-Anhalt, Germany. Environ Sci Pollut Res Int 8(1):27-34

Wang R, Liu G, Chou CL, Liu J, Zhang J (2010) Environmental assessment of PAHs in soils around the Anhui Coal District, China. Arch Environ Contam Toxicol 59(1):62-70

Wei H, Cheng H, Ting M, Wen-Hui Z, Xian-Gui L (2010) A chromosomally based luminescent bioassay for mercury detection in red soil of China. Appl Microbiol Biotechnol 87(3):981-989

Willardson BM, Wilkins JF, Rand TA, Schupp JM, Hill KK, Keim P, Jackson PJ (1998) Development and testing of a bacterial biosensor for toluene-based environmental contaminants. Appl Environ Microbiol 64(3):1006-1012

Yan J, Wang L, Fu PP, Yu H (2004) Photomutagenicity of 16 polycyclic aromatic hydrocarbons from the US EPA priority pollutant list. Mutat Res 557(1):99-108 
Yang L, Wang Z, Xu L (2006) Simultaneous determination of phenols (bibenzyl, phenanthrene, and fluorenone) in Dendrobium species by high-performance liquid chromatography with diode array detection. J Chromatogr A 1104(1-2):230-237
Zhong WH, Cai ZC, Zhang H (2007) Effects of long-term application of inorganic fertilizers on biochemical properties of a riceplanting red soil. Pedosphere 17(4):419-428 